This item was submitted to Loughborough's Research Repository by the author.

Items in Figshare are protected by copyright, with all rights reserved, unless otherwise indicated.

\title{
What to do with literary manuscripts? A model for manuscript studies after 1700
}

PLEASE CITE THE PUBLISHED VERSION

https://doi.org/10.3828/comma.2017.6

\section{PUBLISHER}

(C) Liverpool University Press

\section{VERSION}

AM (Accepted Manuscript)

\section{PUBLISHER STATEMENT}

This paper was accepted for publication in the journal Comma: International Journal on Archives and the definitive published version is available at https://doi.org/10.3828/comma.2017.6

\section{LICENCE}

CC BY-NC-ND 4.0

\section{REPOSITORY RECORD}

Van-Mierlo, Wim. 2018. "What to Do with Literary Manuscripts? A Model for Manuscript Studies After 1700". figshare. https://hdl.handle.net/2134/35210. 


\title{
What to do with literary manuscripts? A model for manuscript studies after 1700
}

\author{
Wim Van Mierlo
}

In 1967 Le Monde printed an article by Louis Hay, a prominent specialist on the work of Heinrich Heine, with the subtitle 'Des manuscrits, pour quoi faire?' Prompting the article was the acquisition of the Schocken collection of Heine manuscripts by the Bibliothèque nationale in which its author had been instrumental. Confronted by a wealth and welter of documents, Heine scholars were presented with an opportunity and a challenge. With well over 2,000 pages of manuscripts, aside from a vast cache of letters, scholars, Hay wrote, had their work cut out for them in ordering, interpreting and editing the materials. In particular, deciphering the poetry manuscripts, full of extensive crossings-out, additions and alterations, would be particularly 'delicate' task for textual critics requiring the application of 'all the technical and scientific resources of their art'. ${ }^{1}$ Hay's fundamental question about what to do with literary manuscripts was rhetorical more than critical. While he intimated an impending change in Heine studies in literary-historical and critical terms, the thrust of the question was a validation of a new 'departure' in literary studies: to study the process of literary production rather than the product. The idea of looking into the poetics of creation was itself not new, but Hay and other scholars around him working on Flaubert, Stendhal and other French authors began working out a new sophisticated critical methodology. Thus 'Critique génétique' became an established field, with its own 'laboratory' within the CNRS, the Institut des textes et manuscrits modernes (ITEM, founded in 1982 on the earlier Centre d'analyse des manuscrits modernes), an academic journal, Genesis: Manuscrits - Recherche - Invention (established in 1992); and numerous seminars, conferences, monographs and essay collections promulgating its methods and applications that eventually generated followers in other parts of the world as well.

Regardless of whether we see it is a cause or an effect, the paradigm shift that the généticiens enacted, highlights the split between those who keep manuscripts and those who study them. Despite sharing an object of study, genetic criticism and archive studies occupy distinct spheres of activity. What to do with manuscripts thus remains a pertinent question. My aim in this article is to outline a new critical framework for the use of literary drafts and manuscripts. My contention is that the theoretical models which archive studies and genetic criticism supply do not entail a holistic approach to the manuscript. To realize such a holistic view requires us to ask once again what the manuscript is for.
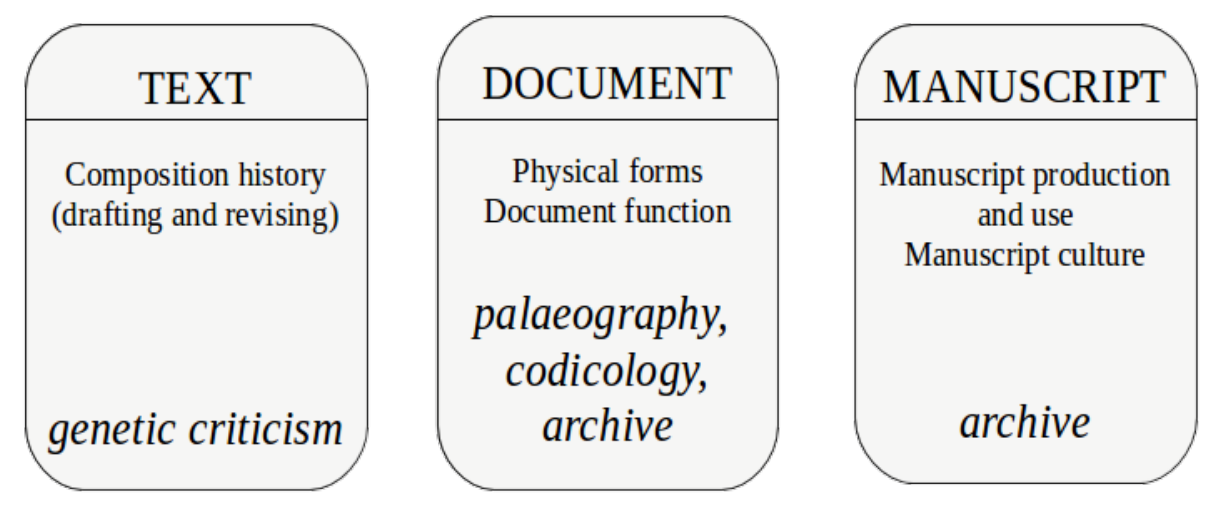

\section{Figure 1: Framework components for the study of literary manuscripts after}

Manuscripts are not just documents that provide windows to the past, nor are they simply witness to a composition process; as psychical, cultural and heritage objects, they are complex and multi-faceted in their attributes: material, form, value and use. Careful study of these attributes can thus significantly enrich our understanding of their production, utility, function, circulation and historical after life.

The very nature of what makes a manuscript 'modern' must also be subjected to scrutiny. The period covered, first of all, is largely arbitrary. The Index of English Literary Manuscripts, and its partial successor, the Catalogue of English Literary Manuscripts, 1450-1700 follows traditional literary-historical periods, designating 1700 as the end of the early

\footnotetext{
${ }^{1}$ HAY, L., 'Après l'acquisition du fonds Heinrich Heine: Des manuscrits, pour quoi faire?' in Le Monde des livres, 8 February 1967, p. 6.
} 
modern and the beginning of the modern manuscript. ${ }^{2}$ French genetic criticism usually puts the starting point to 1881 , the year Victor Hugo bequeathed his papers to the French state; he was the first writer to do so. The British Library does not explicitly divide its literary holdings, but it does designate its modern historical collections as beginning in 1603, the year of Elizabeth I's death that marked the end of the Tudor monarchy. In The Study of Modern Manuscripts, still one of the few comprehensive treatments of the subject, Donald H. Reiman, gives 1640 as an approximate turning point based on an increase in the quantity of manuscripts that survive. ${ }^{3}$

These dates, however, are not predicated on ways modern manuscripts have been defined. For Reiman, the era of the modern manuscript distinguishes itself from previous times in the function of the manuscript: with the advent of the printing press as the prime mode of communication, manuscripts changed from being public to being private documents when they no longer served for the circulation of ideas. ${ }^{4}$ Using a similar premise, French genetic criticism narrows the definition even further and equates the modern manuscript with the draft, 'the working manuscript that up till now has been neglected because of its unaesthetic an unfinished appearance', which it valorizes as a new object worthy of study. ${ }^{5}$ Either definition has validity, but each also has a blind spot. On the one hand, the press and the manuscript coincided as a mode of publication in the early modern period and beyond when manuscripts, albeit on a smaller scale, continued to circulate semi-publicly. The widest-known example are William Wordsworth's manuscripts, which contained some of his most canonical poems, that were known within a small circle of friends until their posthumous publication. On the other hand, limiting manuscripts only to documents of composition excludes manuscripts that are significant for other reasons, such as the scribal copies of Keats's poems, for example, that do not survive in autograph copy.

Both Reiman and genetic criticism base their definition of the modern manuscript on its use function as a private document whose emergence owes much to a new spirit of enlightenment that values individuality and originality. To attribute the creation and survival of drafts to a new mentalité has, however, the air of reducing a historical process to a single moment in time. Materially and formally, rather, manuscripts undergo constant change over time, such as the disappearance of vellum, the appearance of machine-made paper, changes in formal writing hands, the replacement of the quill with the steel pen, the emergence of manufactured notebooks, the invention of the typewriter, and so on. With some of these changes come different uses: when the price of paper drops, first gradually in the eighteenth century, then more radically in the middle of the nineteenth, the proliferation of 'scrap' manuscripts rises, as writers become more profligate and produce an ever-larger number of notes, sketches, rough drafts and versions. But also the value of manuscripts changes as institutions and private collectors begin to acquire the manuscripts of recently deceased and living writers. An early example of such an acquisition is a notebook by John Milton, with revised copies of Arcades, Lycidas and Comus, which was given to the new Wren Library in 1691 by Sir Henry Puckering, a former student of Trinity College; how the manuscript had come in his possession is not known precisely, but it has been suggested that he obtained it from Edwards Phillips, Milton's former pupil. ${ }^{6}$ This desire to collect, however, is not simply predicated on a new cult of personality, but on the same discontinuities that led to the mechanisms of bureaucracy and record keeping. It is no coincidence that the antiquarian movement and the establishment of national archives happen almost simultaneously.

Taken together, such changes can go quite some way towards a better understanding of the modern manuscript as a phenomenon. Modern manuscript studies, however, has been something of a fragmented field. In part this is due to disciplinary silos and periodization. Literary scholars rarely converse with archivists, curators and collectors; it is equally rare for scholars to work comparatively on more than author and across the entire period from the eighteenth to the twentieth century. A broader purview, and a more comprehensive framework, is therefore needed to put the study of manuscripts from the last three centuries on an equal footing with practices in mediaeval and early-modern manuscript studies.

Where is the archive in genetic criticism?

The differences between literary archive studies and genetic criticism, it will be clear, result from the varying aims and perspectives that come with the disciplinary traditions and history of each. Louis Hay made a very important pronouncement for genetic criticism when he said that '[m] anuscripts have something new to tell us: it is high time we

${ }^{2}$ CROFT, P. J. et al., Index of English Literary Manuscripts, 4 vols in 9 parts, London: Mansell, 1980-1993 and BEAL, P., The Catalogue of English Literary Manuscripts, 1450-1700, London: Institute of English Studies, University of London, 2013, <http://www.celm-ms.org.uk/> [accessed 16 January 2018].

${ }^{3}$ REIMAN, D. H., The Study of Modern Manuscripts: Public, Confidential and Private, Baltimore and London: Johns Hopkins University Press, 1993, pp. 17 and 154.

${ }^{4}$ REIMAN, Study of Modern Manuscripts, p. 1 and ff.

${ }^{5}$ DE BIASI, P.-M., Génétique des textes. Paris: CNRS Éditions, 2011, p. 30.

${ }^{6}$ VERITY, A. W., Introduction, in John Milton, Paradise Lost, Books VII and VIII, ed. by A. W. Verity, Cambridge: University Press, 1954, pp. xxxiii-xxxiv and HUNTER, W. B. et al., eds, A Milton Encyclopedia, vol 8., Lewisburg: Bucknell University Press; London and Toronto: Associated University Press, 1980, p. 93. 
learned to make them speak'. ${ }^{7}$ As a historian, Renée Sentilles counters that point: '[a]rchival sources on their own are interesting and historical, but they do not speak'. ${ }^{8}$ Reflecting on the different preconceptions about what the archive is, one might say that both fields exist as tectonic plates that rub against one another as they each move in their own direction.

Of the two archive studies has the broader concern as it deals with the preservation, classification and interpretation of a large class of documents: literary drafts and manuscripts as well as personal records (letters, diaries, journals, ephemera, etc.) whose primary use - although that is not the only viable outcome - is the writing of biography and history. Increasingly, it is also concerned with the archive as place and how it embodies knowledge, and with the hermeneutic and discursive practices surrounding the retrieval of objects and information. ${ }^{9}$ Genetic criticism, by contrast, focuses strictly on the growth of the text; its aim is to understand the work in terms of its gestation by analysing the processes of writing. As such, genetic criticism is interested only in documents that bear witness to the composition history of a literary work (although for convenience documents that are not produced by hand, such as typescripts, page proofs and nowadays computer files, are included). The emphasis lies on analysing the writing that is contained within it; an analysis of the physical nature of the documents is only of a secondary concern.

The difference between the two fields is thus not fundamental; both can be said to be processual. The archive, according to Anita Helle, is not a static trove of paper self-evidently revealing its stories, but an 'informing matrix' from whose networks we need to unravel the 'tangled connections' of its 'histories, temporalities, narratives [and] contingencies'. ${ }^{10}$ Genetic criticism analyses, with equal measure, the dynamic forces of creativity and the interplay between writing stages or avant-textes. The difference broadly comes down to a distinction between the manuscript as material object and the role it fulfils within composition. A notebook and a bundle of loose paper leaves are physically entirely different, but a writer may use either one for a first draft or sketch.

Genetic criticism, when it emerged as a new critical approach, defined itself in terms of a theoretical and methodological advance on other forms of literary scholarship, not in the least philology and textual criticism. On the one hand, this self-definition centred upon its new object of study - the manuscript draft - but also upon a new conception of literary study, setting aside the 'product', the finished text or the published work, in favour of the 'process', the act of writing, the moment of invention. To this object they also brought a newly created, sophisticated toolset and discourse for the analysis of the manuscript draft. The archive, however, did not feature, except in passing, in its genealogical rhetoric. Given the initial encounter with the Heine archive, this strikes one as surprising, but understandable in the context of happened. The chaos the Heine scholars came across in the papers was unfamiliar and unusual, even in comparison with most of the archival and historical materials that constituted France's cultural heritage.

Archives in France, as in other European nations, are a national matter. The idea of creating a national archive came in 1790 when the new Revolutionary administration decreed that state documents should be kept centrally and open to the public. In 1808, the Archives nationals moved to its own dedicated building, the Hôtel de Soubise, and three years later, in 1811, adopted its first official classification system. The Archives, however, were run by civil servants; it would take a decade or more before they began hiring specialist staff trained at the École de Chartres, established in 1821, which, charged with the task of reading and understanding the nation's ancient documents and manuscripts, took up the study of palaeography and philology. Another ten to twelve years were to pass before accessioning tools in the form of catalogues and inventories came in use. Up till then the Archives nationales had largely serve the administration of the State; in 1867, Henry Bordier, its former archivist, begrudgingly acknowledged that the Archives had finally been transformed into 'an office of History'. ${ }^{11}$ It was a turning point that marked the foundation of history as a discipline in France. $^{12}$

But what about literary archives? Since the resetting of the historical clock at the time of the French Revolution, the Archives nationales served as the repository for all administrative documents produced by the new Republic; the old archives from the Ancien Régime joined the historical documents, manuscripts and charters documenting France's

${ }^{7}$ HAY, L., 'History or Genesis?', in CONTAT, M., HOLLIER, D. and NEEFS, J. (eds.), Drafts, special issue of Yale French Studies, 89, 1996, pp. 191-207 at p. 207.

${ }^{8}$ SENTILESS, R. M., 'Toiling in the Archives of Cyberspace', in BURTON, A. (ed.), Archive Stories: Facts, Fictions and the Writing of History, Durham and London: Duke University Press, 2005, pp. 136-156 at p. 140.

${ }^{9}$ HELlE, A., 'Introduction: Archival Matters', in HELLE, A. (ed.), The Unraveling Archive: Essays on Sylvia Plath, Ann Arbor: University of Michigan Press, 2007, p. 1-14 at p. 3-4.

${ }^{10}$ HELLE, A. 'Archival Matters', p.1.

${ }^{11}$ Qtd. in MILLIGAN, J. S., "'What Is an Archive?" in the History of Modern France', in BURTON, A. (ed.), Archive Stories: Facts, Fictions and the Writing of History, Durham and London: Duke University Press, 2005, pp. 159-183 at p. 176.

${ }^{12}$ FAVIER, J. Les Archives, 4th ed. Paris: Presses universitaires de France, 1985, p. 34; MILLIGAN, 'What Is an Archive?', p. 171, 176. 
mediaeval history already in the Bibliothèque nationale, creating a sharp division between administration on the one hand and art, history and sciences on the other. ${ }^{13}$ The natural place for modern literary papers therefore was the Bibliothèque nationale where they complemented the printed collections and built up the national literary patrimonium. Hugo's will had been instrumental in the creation of a department of modern manuscripts. ${ }^{14}$ Nonetheless, the Library's holdings of eighteenth- and nineteenth-century authors were perhaps more collection than archive. ${ }^{15}$ To this one should add that the primary function of the holdings was as source. So, on the one hand, the purpose of pre-modern literary and historical documents was to write the history of the nation; palaeography and diplomatic served as specialist auxiliary fields to describe, decipher and analyse to open these documents up to historical research. On the other hand, literary papers from the modern period were looked at more piecemeal; letters and diaries posed less of a problem for reading, while manuscripts, which served as sources for philology and scholarly editions, were of interest only if they could furnish authoritative variants not available from printed editions. Anything that was not a fair copy received practically no attention at all. ${ }^{16}$

When in other words the first genetic critics directed their efforts to the Heine papers, they were confronted with something of skills gap. Louis Hay remembers how the 'first experience of the généticiens consisted of discovering, behind the familiar and stable shelves of the Library, the unknown space of the Archive, and of entering a new universe of discovery that was totally new to academics'. However, it was not only because they were literary scholars that they did not know how to 'inventory, classify or even describe them'; there hardly existed any methodologies for this kind of work at all. ${ }^{17}$ They turned to the experts in mediaeval philology at the Institut de recherches et d'histoire des textes (IRHT) in the CNRS, who helped them apply the traditional methods palaeography and codicology to modern manuscripts.

Nonetheless, the division that Hay flags up between the university and the archive is of consequence. As students of literature, the généticiens were in the first instance interested in language. Their 'point of departure' may have been the material document, but their 'point of arrival' was 'interpretation'. ${ }^{18}$ Almost from the start, genetic criticism was more focused on manuscripts as 'text' and 'writing' than it was interested in the documentary nature of the manuscript. The extent to which the archive simply did not fall within the genetic compass owes much to the new perspective that focused on particular documents that contained evidence of a textual process. ${ }^{19}$ Expositions on the theory and methodology make this stance quite apparent.

Pierre-Marc de Biasi, one of the most influential theoreticians of genetic criticism, defines two distinct phases in manuscript work. '[G]énétique textuelle' concerns itself with preliminary analyses - the organization, classification, deciphering and transcription of the documents - that opens the manuscripts up to 'critique génétique' or the interpretation proper of the processes of writing. The physical manuscript is, otherwise said, largely an inert object. Either it is a thing to be possessed and thus belongs to 'library curator's jurisdiction': as a 'definitive' version of the work, it merely stands at the end-point of the genesis that preceded it. Or it can be set aside as soon as the impediments of its materiality have been removed and the real work of interpretation can begin. ${ }^{20}$ Explicitly deprivileging the physical document, Louis Hay, in a retrospective view on the history of genetic criticism, speaks triumphantly about the new enthusiasm for the manuscript, but in the same breath denigrates the archival perspective: 'This confrontation with the manuscript, an object unknown in the University, would create a shock expressed in 1967 by the title of a first article [in Le Monde]: "What to do with Manuscripts?". This is evidently a question that no archivist had ever asked himself'. 21

${ }^{13}$ MILLIGAN, 'What Is an Archive?', p. 162.

${ }^{14} \mathrm{DE}$ BIASI, Génétique des textes. p. 20.

${ }^{15}$ See SACQUIN, M. 'Les manuscrits littéraires du XVIII' siècle à la Bibliothèque nationale de France', in Genesis: Manuscrits - Recherche - Invention, 34, 2012, <http://journals.openedition.org/genesis/966> [accessed 2 March 2018], especially \#36-40.

${ }^{16}$ LEBRAVE, J.-L., 'La critique génétique: Une discipline nouvelle ou un avater moderne de la philologie?', in Genesis: Manuscrits - Recherche - Invention, 1, 1992, pp. 33-72 at pp. 65-67.

${ }^{17} \mathrm{HAY}, \mathrm{L}$. 'Qu'est-ce que la critique génétique?', in ITEM: Articles en ligne, <http://www.item.ens.fr/articles-enligne/quest-ce-que-la-critique-genetique1/>, 2008 [accessed 26 February 2018] and HAY, L. 'Édition critique et génétique','Édition critique et génétique: Du moyen âge à nos jours', in VAUTHIER, B. and GAMBA CORRADINE, J. (eds.), Crítica genética y edición de manuscritos hispánicos contemporáneos: Aportaciones a una 'Poetica de transición entre estados', Salamanca: Ediciones Universidad de Salamanca, 2012, pp. 147-58 at p. 151.

${ }^{18} \mathrm{HAY}$, 'Qu'est-ce que la critique génétique?'

${ }^{19}$ LEBRAVE, 'La critique génétique', p. 66.

${ }^{20} \mathrm{DE}$ BIASI, Génétique des textes, p. 12 and 'Toward a Science of Literature: Manuscript Analysis and the Genesis of the Work', in DEPPMAN, J., FERRER, D. and GRODEN, M. (eds), Genetic Criticism: Texts and Avant-textes (Philadelphia: University of Pennsylvania Press, 2004), pp. 26-68 at p. 43 and 44.

${ }^{21} \mathrm{HAY}$, 'Édition critique et génétique', p. 151. 
The genetic 'démarche' was thus injected with the discourses of modernity. As a method, genetic criticism wasn't just new; it didn't only upgrade the manuscript from a precious literary relic to a new object of study; it invented an entirely new conception of the manuscript. To de Biasi's mind, the genetic study of texts brought with it 'a new object structured by time: literary writing as process, the work as genesis'. ${ }^{22}$ Furthermore, this invention went hand in hand with adopting a mixture of new concepts, such as avant-texte, and terms like dossier génétique. Indicative of the focus on text, the avant-texte is in fact a very peculiar concept; it does not seem unlikely in fact that its meaning was retroengineered from. The term certainly seems to have had a general valency as a not-yet-completed text at least as early as the 1950s. (In a book on jurisprudence, Lucien Siorat uses avant-texte in this literal sense to explain how having recourse to the genesis of a text can clarify the will of its author.) ${ }^{23}$ Hence, de Biasi belabours the point that the avanttexte does not correspond to the raw material of writing in the manuscript but was in fact a construct: the result on the one hand of an editorial intervention that renders the text in its temporal form in the order in which it was inscribed (although the word 'editorial' itself was eschewed); and the result of a critical intervention on the other. The avant-texte is not an entity, but rather it was itself 'a study of the genesis', 'an elucidation of the logical systems that organize it'; the avant-texte therefore does not really have any independent existence 'outside the critical discourse that produce[d] it'. ${ }^{24}$ As a consequence, to make a distinction between this reconstitution and the documents from which the avant-texte was derived, it was necessary to introduce another term: dossier génétique or 'dossier d'un œuvre'.. ${ }^{25}$ Although a term used in archive studies, its meaning here fully corresponds to neither document, file (dossier in French) or fonds, but refers to the complete run of extant documents (regardless of physical form or location) that belong to a work.

$\% \% \%$ Fundamentally, genetic criticism favours text and writing over document. To be sure, the awareness that an understanding of how a document was physically made, and how a writer used his manuscripts, can be crucial to unraveling the creative process is well understood. Analyses of material features of the support are not absent. Claire Bustarret has done important work on developing codicological principles for modern manuscripts. ${ }^{26}$ Almuth Grésillon describes some common features of 'graphic spaces' associated with authors' habits of writing: wide margins or no margins at all, interlinear v. marginal revisions, orientation of the writing, etc. ${ }^{27}$ Extending these gestures of writing into a topography of the manuscript, other recent work, influenced by the possibilities offered in digital manuscript editing, contemplates how 'the document space was filled in the course of composition'; it posits the writing as threedimensional and multi-layered as it appears on the 'two-dimensional surface' of the support. ${ }^{28}$ The work of these scholars, in many ways fundamental, is limited in others. Bustarret's investigations are mainly intended to resolve questions of provenance and dating, while Grésillon's observations tend to highlight the idiosyncratic; the topographic approach is a purely functional one that parses the space of the manuscript in order to unravel the sequence of inscription. The manuscript as creative space - not just in the metaphoric sense but also in the actual uses and experiences of space - is therefore one that requires further investigation. After all, the manuscript is not only a record of composition, but also, as Dirk Van Hulle argues, an extension of the author's mind: an instrument for thinking. ${ }^{29}$ Such a genetics of space is at once the missing link that connects genetic criticism with archive studies.

From genetic record to manuscript culture

The manuscript functions as a tool to capture and kindle creativity, but the capabilities of this tool are not boundless. By way of suggesting a parallel, think for a moment of the digital tools and apps that we use, the affordances they offer and the restrictions we have to contend with. Thus, the physical attributes of the manuscript, together with all the other paraphernalia of writing that the writer uses, have a direct effect, positive and negative, on the cognitive processes involved in literary creation. The page can liberate or limit, stimulate or inhibit the 'textualizing', the process by which ideas are rendered into writing, of the work. ${ }^{30}$ Understanding the ontology of the document, by which I mean its culturally and socially determined uses, is an important step towards understanding what happens in the black box of

\footnotetext{
${ }^{22} \mathrm{DE}$ BIASI, Génétique des textes, p. 6-7; see also HAY, 'Genèse de la génétique'.

${ }^{23}$ SIORAT, L., Le problème des lacunes en droit international: Contribution à l'étude des sources du droit et de la fonction judiclaire, Paris: Librairie Générale de Droit et de Jurisprudence, 1958, p. 80.

${ }^{24}$ DE BIASI, 'Toward a Science', p. 43, my italics.

${ }^{25}$ Lebrave, 'La critique génétique', p. 66.

${ }^{26}$ BUSTARRET, C., 'Paper Evidence and the Interpretation of the Creative Process in Modern Literary Manuscripts', L'esprit créateur, 41, 2001, pp. 16-28.

${ }^{27}$ GRÉSILLON, Almuth, Éléments de critique génétique: Lire les manuscrits modernes, Paris: Presses Universitaires de France, 1994, pp. 51 and ff.

${ }^{28}$ GABLER, H. W., 'The Draft Manuscript as Material Foundation for Genetic Editing and Genetic Criticism', Variants: The Journal of the European Society for Textual Scholarship, 12-13, 2016, <http://variants.revues.org/299>, [accessed 28 June 2017], pp. 65-76 at p. 68.

${ }^{29}$ VAN HULLE, D., Modern Manuscripts: The Extended Mind and Creative Undoing from Darwin to Beckett and Beyond, London: Bloomsbury, 2014.

${ }^{30}$ DE BIASI, Génétique des textes, p. 90.
} 
literary creation. We might understand this process as an archaeology of the manuscript, a study of the sedimentation of the genetic layers that is to be brought in contact with literary history, cultural history and the history of writing.

A critical framework for the study of literary manuscripts, in other words, would comprise three components (see Figure 1): an analysis of the genetic history of the work, a codicological and palaeographical investigation of the relevant documents and a consideration of the cultural dimensions that give the writing and those documents meaning and value.

Genetic history: Genetic criticism is about the interpretation of the writing process at a moment when the final work is not only unfinished but unforeseeable, of a 'writing in search of itself' which thus exists in a state of perpetual transformation and 'permanent possibility'. ${ }^{31}$ While purporting to analyse invention and the poetics of creation in these terms, genetic criticism purposefully desacralizes inspiration and shies away from pronouncing directly on creativity and the imagination itself. ${ }^{32}$ It observes invention, makes sense of the material traces and describes the mechanisms by which a text came into existence, but it in effect considers the author's mind closed off, invisible, and beyond analysis. As a result, genetic criticism only partially comes to terms with how creativity happens.

Despite adhering to a 'theoretical (post-Heideggerian, phenomenogical) denial of individual creative origins an of creative agency', Sally Bushell nonetheless contends that one cannot simply bypass the creative mind that produced the work; she deems it essential to understand composition 'both in terms of will, intention, linearity, teleology' and 'in its relation to potential 'authenticity' lest drafts are simply understood as fragmented, multiple texts whose relations to one another are undetermined and non-expressive. Her plea to retain 'an expressive model of literary creativity' is taken to its logical extreme in Dirk Van Hulle's 'enactive' approach to literary manuscripts. ${ }^{33}$ Insofar as authors do not simply write down what they first composed in their head but think on paper, he sees manuscripts not as archive containing the record of composition, but (drawing on the work of cognitive psychologists Richard Menary and Andy Clark and David J. Chalmers) as tool which is, literally, an extension of the author's mind. The interaction with the manuscript cognitively generates two-way traffic between the author's creative impulses and the material environment in which this happens: the manuscript influences, in certain respects conditions, literary creation.. ${ }^{34}$

It should be clear that the 'enactive model' does not really bring us any closer to actually understanding the processes of the imagination, so celebrated by the Romantic poets, but as a model it goes some way to explaining the act of creation in a manner that does not settle for mechanistic descriptions of the stages in the growth of a text.

Physical attributes: Nonetheless, an expressive or enactive understanding of literary creation must be grounded in an understanding of the physical attributes of the manuscript: its format (size, weight, thickness, etc.), medium (e.g. loose papers, notebook), use (in particular how the space of the page is used) and function (sketch, working draft, fair copy, printer's copy, page proof, etc.). If the manuscript impacts on the writing, we must be able to analyse the material clues. This requires a new advanced methodology - a palaeography of the modern manuscript. ${ }^{35}$ Given that the formal structures of modern manuscripts are far less regularized than their mediaeval counterparts, establishing palaeographical principles is naturally far from straightforward. Yet its necessity should be evident.

In genetic criticism, the move from genetic dossier to avant-texte is predicated on translating the space of the manuscript into the temporal sequence of composition. But while this has been the primary aim for decades, the method by which this happens is still in a need of a more rigorous, systematic approach than is currently available. The space of the manuscript entails a veritable geometrics of writing that consists of a multitude of parameters. Some are quite obvious, and are culturally determined: in the West writing moves from left to right and top to bottom. Others are more subtle, yet part of customary behaviour: interlinear insertions and substitutions tend to go above the line, but can go below as well, especially when there is insufficient space. Still others exist at such a minute level of detail and appear so idiosyncratic that we may barely notice them. One can, for example, detect changes in handwriting within a single document or even a single page? But how does one 'read' those changes? Are they indicative of a new stage in the writing? Of a change in the writer's state of mind? Or are they simply coincidental?

Once we begin to think about the space of the manuscript in any detail, the questions that arise from it multiply quickly. Does every cancellation have the same valency? Is it significant when a writer turns a page sideways? Is there any

${ }^{31}$ DE BIASI, Génétique des textes, p. 10, 41.

${ }^{32}$ MITTERAND, H., 'Le méta-texte génétique dans les Ébauches de Zola', Genesis: Manuscrits - Recherche Invention, 6, 1994, pp. 47-60 at p. 47. See also LEBRAVE, 'La critique génétique', p. 67.

${ }^{33}$ BUSHELL, S., Text as Process: Creative Composition in Wordsworth, Tennyson, and Dickinson, Charlottesville and London: University of Virginia Press, 2009, p.6.

${ }^{34}$ VAN HULLE, Modern Manuscripts, p. 4, 130, 148-49. See MENARY, R., 'Writing as Thinking', Language Sciences, 5, 621-32 and CLARKE, A. and CHALMERS, D. J., 'The Extended Mind', Analysis, 58, 10-23.

${ }^{35}$ See VAN MIERLO, W., 'The Archaeology of the Manuscript: Towards Modern Palaeography', in SMITH, C. and STEAD, L. (eds.), The Boundaries of the Literary Archive: Reclamation and Representation, Farnham, Surrey: Ashgate, 2013, pp. 15-29. 
meaningful reason as to why a writer chooses a pencil, pen or even a typewriter? Likewise, how is writing on loose leaves different from writing in a bound copybook? How do we assess writing that is copied and revised as opposed to re-written? (This is a question that is especially important with poetry where memory plays a much greater role than in the copying of prose.) How do we tell the difference between a fair copy and a neatly written draft? (The manuscript of John Keats's 'Ode to a Nightingale', usually taken to be first and only version, may provide a case in point.) Do writers plan - and leave space for - revisions and how? Is there a difference in meaning and value between revisions and currente calamo revisions? Is there in fact a neat boundary between writing and revision? How can we tell that writing was easy, inspired, flowing versus writing that was difficult, laboured, halting? All of these questions reflect features in the manuscript that are observable and provide clues as to the creative process. The ultimate question is: what do these clues tell us?

As with mediaeval manuscripts, the material form of modern manuscripts is not incidental, albeit that it is more varied. As with printed books, whose 'forms of visual evidence in the books themselves' act 'as determinants of meaning', the material affordances and constraints in manuscripts are determining factors in the making of a work. Not just the words authors invent, but the way they use the page is indicative of a creative economy. A modern palaeography is therefore concerned with much more than, as Hay maintains, the highly individualized nature autograph traces. ${ }^{36}$ What may seem idiosyncratic is in fact evidence of larger patterns.

Manuscript culture: The use the page is subject to cultural practices that extend and have remained remarkably constant over time. The notebook as a cultural phenomenon exemplifies this. Differences in format and idiosyncrasies in usage notwithstanding, writers' notebooks of writers show a high degree of commonality in their primary functions and their affordances. Portability, first of all, was an important feature of its ergonomics so that thoughts, ideas and impressions could be recorded or retrieved on the spot. At its most basic, notebooks were intended to be ephemeral, simply serving its owner as a mnemonic device. Notebooks were generally used for all sorts of information: addresses, accounts, to-do lists, notes, etc. A notebook that Dorothy and William Wordsworth carried with them to Germany in 1798 contains an account of their journey, language lessons, notes from a conversation with Klopstock, a draft essay as well as early draft materials for The Prelude and, added later, sections of Dorothy's journal. ${ }^{37}$ But as such notebooks also had the capacity to serve as a 'commonplace' books to store, organize and index information for later use. George Crabbe kept fair copies of his lyrical composition together in his notebooks (although he also used them for drafting); W. H. Auden neatly fair-copied his poems in school copybooks. ${ }^{38}$ James Joyce often was in the habit of transcribing and arranging his notes in school copybooks under designated headings, sometimes topical or generic headings but frequently also under chapter titles. ${ }^{39}$ The commonality in these uses are not coincidental but are the result of learned cultural behaviour.

Even more so than with the palaeographical evidence, these cultural practices have barely been studied at all. In a wellknown remark, Daniel Ferrer posits that a draft "is not a text", but "a protocol for making a text". ${ }^{40}$ Ferrer is right to say that writing is not teleological and that therefore its outcomes are not completely predetermined by its inception. But nor are these outcomes totally separated from their inception either. No work ever comes into being in a complete vacuum, but is subject to a matrix of external influences - influences that are varied and diverse, but sometimes also vague and immaterial: sources the author is reading, stuff she has written earlier, desires and intentions concerning subject matter and style, expectations about readership, and ambitions about impact, market success and reputation. These influences also include the tools the writer uses for writing. The implications of Ferrer's remark, therefore, go (I believe) beyond those he intended. For these protocols of making are reliant upon - indeed, cannot take place without the implements the writer uses for writing, the supports on which she inscribes her text or the purpose for which the support is used.

The main purpose of a page proof, for instance, is to check whether the text is typographically correct before publication. For many writers, however, it serves as an occasion truly to assess the quality of their work for the first time: seeing their text in cold print offers distance in which they feel they can read their text objectively without the encumbrance of handwriting, deletions and revisions. Alfred, Lord Tennyson, although he is by no means the only poet to do so, even went so far as to order multiple proof sets to decide on the selection and order of his poem in his

\footnotetext{
${ }^{36} \mathrm{HAY}$, 'Qu'est-ce que la critique génétique?'

${ }^{37}$ The notebook is at The Wordsworth Trust, Grasmere under shelfmark DC MS 19

${ }^{38}$ Two of Crabbe's notebooks are in the Cambridge University Library, with shelfmark MS Add. 4422 and 4423. The

British Library has several Auden notebooks, with shelfmark Add. MSS 52,430, 53,772 and 89,035.

${ }^{39}$ Several examples are in the National Library of Ireland, with shelfmarks NLI 36,639/01 to 36,639/05/B. See CRISPI, L., 'A First Foray into the National Library of Ireland's Joyce Manuscripts: Bloomsday 2011', in Genetic Joyce Studies, 11, 2001, <http://www.antwerpjamesjoycecenter.com/articles/GJS11/GJS11_Crispi> [accessed 5 March 2018].

${ }^{40}$ FERRER, D. 'The Open Space of the Draft Page: James Joyce and Modern Manuscripts', in BORNSTEIN, G. and TINKLE, T. (eds), The Iconic Page in Manuscript, Print, and Digital Culture, Ann Arbor, Mich.: University of Michigan Press, 1998, pp. 249-268 at p. 261.
} 
volumes: "My MSS (i.e. those I have by me) are far from being in proper order [...]. I scarcely know at present what size the volume will be, for I have many Poems lying by me with respect to which I cannot make up my mind as to whether they are fit for publication". ${ }^{41}$ How the choice of support impacts on the writing is illustrated by W. B. Yeats. Yeats's normal practice was to draft on small-sized loose leaves whose constricted space led him to fill the pages entirely. When he switched to a sumptuous, folio-sized, vellum-bound notebook - a gift from Maud Gift - the writing appears to explode across the page, with lots of space left blank and big lines connecting various bits of poetry all around and across the page. It would be incorrect to say that the ample space gave Yeats greater freedom creatively; however, it does clearly give a different dynamic to the composition.. ${ }^{42}$

What these examples illustrate is that manuscripts are than just instrumental; they are an embodied tool that like other tools, as Van Hulle contends, is a an extension of the mind. The proverbial blank page is not, paradoxically, a blank canvas; it has its own protocols of use that direct the writing. It also has its own economies of function that that link into larger mechanical, organizational, cultural and even socio-economic systems.

\section{Conclusion}

The archive as a lieu de mémoire is the locus where these systems come into play. Archives are much more than places that conserve records, safeguard the past and make history accessible. The archival record, as we have known for some time now, is never self-evidently transparent; its meanings can never exhaustively be made manifest. Instead, archives require interpretation. In the words of Jean Favier, head of the Archives nationales from 1974 to 1994, archives are 'the new laboratories of History'.. ${ }^{43}$ As the enabler of historiography, 'archives are before anything else inert materials that are in need of being opened up'. ${ }^{44}$ The term that he uses in French is 'mise en œuvre': the documents literally need to be put to work. Favier, however, was still a proponent of the idea that the archive was merely the source, while criticism was the instrument, meaning that to work the archives first needed to be organized, catalogued and made accessible. ${ }^{45}$ But despite his positivist intent, this 'opening up' nonetheless points to a need for interpretation. Archives are the place where history is made.

In this context, it is important to remember how much genetic criticism is a reaction too against the positivist norms that reigned in France until the late sixties. But, as I have been making the case, the pendulum swung almost totally to a critical hermeneutic that sought to make sense of the processes of literary creation to the detriment of studying wider literary historical and cultural aspects of the manuscript. ${ }^{46}$ It is surprising, for instance, how little explicitly comparative work actually exists. In the model I propose, this would be readily resolved, for to consider the genetic history of a work in the light of that work's archival constitution - to see the manuscript not just as writing, but as a physical document, a record of its inscription, an instrument for writing, a creative space, and a culturally valorized object - is to consider it outside of the constricted perspective of the individual author and her idiosyncrasies. What is crucial is not what makes the manuscripts of authors unique and different, but what makes them indifferent as an expression of a shared time and place, a product of their culture.

To move away from the accepted notion that manuscripts in the period after 1700 are idiosyncratic that reflect their author's individual practices, we need to look more closely at the connections between the history of the text, the physical document and its archival value, the social, cultural and legal frameworks within which the document is situated. Each of these connections is relevant and informative, no matter in which direction one is looking: towards the minutiae of genetic development or towards a culture of writing.

Perhaps one of the unappreciated challenges that students of literary composition and literary archives are confronted with is the immateriality of the creative process. Metaphors such as looking into the writer's workshop or laboratory may overlook an important aspect of manuscript work, which, strictly speaking, does not study the processes of composition, but only the material traces of that process in a way that an archaeologist studies the material remnants of human settlement and civilization. Archives consist of 'bits of flotsam' that one collects and that allow one 'to make educated decisions' about the material - what it is, why it was used and how it fits with other materials - in a way that can separate fiction from fact. ${ }^{47}$ The documents that bear witness to the genesis of the work in literary archives are similarly fragmented, but at the same time their 'informing matrix' (to use Helle's phrase again) is incredibly complex; the number of interrelated components is not only high but also crosses different levels: text to text, text to work, text to

${ }^{41}$ The Letters of Alfred, Lord Tennyson, Vol. 1: 1821-1805, ed. by LANG, C. Y. and SHANNON, E. F, Cambidge, Mass: The Belknap Press of Harvard University Press, 1981, pp. 80-81.

${ }^{42}$ The notebook is at the National Library of Ireland, designated Rapallo Notebook D with shelfmark NLI 13,581.

${ }^{43}$ FAVIER, Archives, p. 37

${ }^{44}$ FAVIER, Archives, p. 66, my emphasis.

${ }^{45}$ See FAVIER, Archives, p. 24.

${ }^{46}$ See BLOOMFIELD, C. 'Du document à l'archive: L'historien de la littérature face à ses sources', in Littérature, 166, 2012, pp. 69-83 at p.73.

${ }^{47}$ Sentilles, 'Toiling in the Archive of Cyberspace', p. 147. 
document, document to document, document to work, document to archive, and so on. To move from the material to the immaterial, therefore, requires a leap of the imagination that is best served only when the manuscript is looked at holistically. 